\title{
SUBMICROSCOPIC STRUCTURE OF THE HUMAN SYNOVIAL MEMBRANE
}

\author{
D. HORKÝ \\ Department of Morphology, University of Veterinary Science, 61242 Brno \\ Received fanuary 14, 1980
}

\begin{abstract}
Horký D.: Submicroscopic Structure of the Human Synovial Membrane. Acta vet. Brno, 50, 1981: 3-25.

In the present study described are the ultrastructure of cells of the synovial membrane, composition of the intercellular substance and the appearance of the synovial membrane in a scanning electron microscope of 38 individuals of the age from 12 to 67 years. The synovial membrane consists of specifically modified cells, which can be differentiated into types $A$ and $B$ according to studies of their submicroscopic structure, and of the intercellular substance. Under the synovial membrane proper the subsynovial tissue is deposited. The surface of the synovial membrane consists of one to four layers of cells. A cells predominate in the cellular population, whereas cells of the B type are much less numerous. Short portions of the synovial membrane are covered by the intercellular substance only, thus being in direct contact with the joint cavity. There is a small number of cells of the B type in a normal synovial membrane. They are deposited mainly near the surface of the synovialis. Besides cells of the A and B types there is a variable amount of transient cellular forms in the human synovial membrane which have some common characteristics of both of the clean-cut types. Their occurrence depends on the physiological condition of the joint. The ground fibrillar substance is made of fibrillar structures of two appearances. On the one hand, they are collagen fibrils $60-100 \mathrm{~nm}$ wide and as much as several $\mu \mathrm{m}$ long with a periodicity of $64 \mathrm{~nm}$, on the other hand, they are aperiodic fibrils of a width of around $50 \mathrm{~nm}$ and length on average $0.1 \mu \mathrm{m}$. The ground amorphous substance, into which the fibrillar component is placed, consists of a complex of protein-hyaluronic acid and sulphonated mucopolysaccharides. The appearance of the subsynovial tissue in the author's material is fibrous. The intercellular substance is represented by enormous bundles of collagen fibrils running in various directions. There are no aperiodic fibrils. The appearance of the synovial membrane in the scanning electron microscope is that of a frilled tissue on the surface of which we can observe protrusions separated by notches. The protrusions are caused both by the cells and their projections and by collagen fibrils penetrating into the superficial layers of the synovial membrane.
\end{abstract}

Human synovialocytes $A, B$, synovial matrix, scanning electron microscopy, synovial membrane surface.

The structure and function of a normal synovial membrane have been studied for a long time. The first data were published more than two hundred years ago (Hunter 1743), followed by Bich at (1800), Brodie (1834), Key (1925), Walcott (1927) - (quoted see Stone 1947). The microscopical structure of the synovial membrane was then studied by many authors and its structure was described under normal conditions, experimental conditions and also pathological changes on animal and human material (in summary see e. g. Jaffe 1972).

The first studies on synovial membrane on an electron microscopic level were published by Langer and Huth (1960), Wyllie et al. (1964) in guinea-pigs, Ghadially and Roy (1966) described the rabbit synovial membrane, as well as Mitchell and Blackwell (1968), Muirden and Peace (1969), later Cherney et al. (1970), Krey and Cohen (1973), Watanabe et al. (1974), Krey et al. (1976), Oryschak and Ghadially (1976), Watanabe et al. (1976a, b) and 
others. Roy and Ghadially (1967), Wassilev $(1972,1973,1975)$ dealt with the synovial membrane of rats, Howlett (1974) with that of cattle, Johansson and Rejnö (1976) with that of horse.

The ultrastructure of human synovial membrane was described for the first time in the work of Lever and Ford (1958), but most knowledge about this tissue was provided in the work of Barland et al. (1962) which is considered to be classical and the great majority of studies published later follow from it. In the same year Coulter (1962) published a study about the human synovial membrane. Of all the numerous later publications we mention the studies of Rayns.and Highton (1966), Roy (1966), Roy et al. (1966), Ghadially and Roy (1967b, 1969), Bozděch and Hor n (1970), Huth et al. (1973), Klein (1974), Maldyk et al. (1974), Wolf (1974a, b), Poole et al. (1976) and others. Not only do these authors bring new knowledge about the structure of the synovial membrane under normal conditions, but they compare its appearance and fine structure under some pathological conditions and/or under experimental conditions, or they deal with the function of the synovial membrane (Maibach 1953, Castor 1960, Hamermann et al. 1961, Ball et al. 1964, Cochrane et al. 1965, Adam 1966, Vainio 1966, Ghadially and Roy 1967a, Luckenbill and Cohen 1967, Muirden and Senator 1968, Webb et al. 1969, B haw an et al. 1973, Cchiu 1975). In earlier studies (Lever and Ford 1958, Ghadially and Roy 1967b, 1969) it had already been found that there were no differences in the fine structure of the synovial membrane of various age categories and that there were only small differences in the appearance of the synovial membrane of the different joints in man and other mammals.

\section{Materials and Methods}

For studies of the ultrastructure of the synovial membrane tissue samples were taken from the hip joint of 38 individuals of the age from 12 to 67 years. The material was taken either in cases of total endoprostheses performed due to advanced arthrosis, or during operations performed because of other, mostly tumorous, diseases localized outside the joints.

The synovial membrane was taken behind the transitional zone from various regions of the joint capsule. Taken were $1 \times 1 \times 2 \mathrm{~mm}$ strips with part of the subsynovial tissue. In all cases fixation was done with $3 \%$ glutaraldehyde of a pH 7.4, then the tissue was washed in $0.1 \mathrm{M}$ phosphate buffer with $5 \%$ of glucose of a pH 7.4 and then fixed with $1 \%$ of $\mathrm{OsO}_{4}$ according to Millonig in a-phosphate buffer of a pH 7.4. The blocks were embedded into Epon-Araldit or Durcupan ACM. Ultrathin sections were cut on a ultramicrotome Tesla BS 490, Reichert Omu 3 and LKB Ultrotome III and were stained with lead citrate or with $1 \%$ uranylacetate and lead citrate. The sections were studied and photographed with an electron microscope Tesla BS 613 and Tesla BS 500.

For investigations of disorders of the synovial membrane using a scanning electron microscope, $5 \times 5 \mathrm{~mm}$ blocks were left for 3 to 4 hours before fixation in a solution of hyaluronidase in a concentration of $0.1 \mathrm{mg} / \mathrm{ml}$ at a temperature of $4{ }^{\circ} \mathrm{C}$. Afterwards, the samples were fixed with $10 \%$ formol or glutaraldehyde for 1-3 days, dehydrated and coated with gold or platinum on a Balzers coating apparatus and were studied using a Stereoscan Cambridge scanning electron microscope.

The material was sampled and elaborated at the Department of Histology and Embryology of the Faculty of Medicine, J. E. Purkyně University Brno, in cooperation with the Department of Orthopaedy.

\section{Results and Discussion}

Submicroscopic structure of cells of the synovial membrane and synovial matrix

The surface of the synovial membrane generally consists of one to four layers of cells. Their shapes differ from polygonal cells with oval nuclei to flattened cells with spindle-shaped nuclei resembling fibroblasts. They form a more or less compact layer but they are not closely attached as e. g. the epithelium cells (Fig. 1). In the intercellular substance, indicated as synovial matrix, the cells are arranged relatively infrequently in the synovial membranes of the rabbit, guinea-pig and man (Barland et al. 1962, Coulter 1962, Wyllie et al. 1964, Ghadially and Roy 1966, Roy 1966, Roy et al. 1966, Ghadially and Roy 1967b, Mitchell and Blackwell 1968, Cherney et al. 1970, Huth et al. 


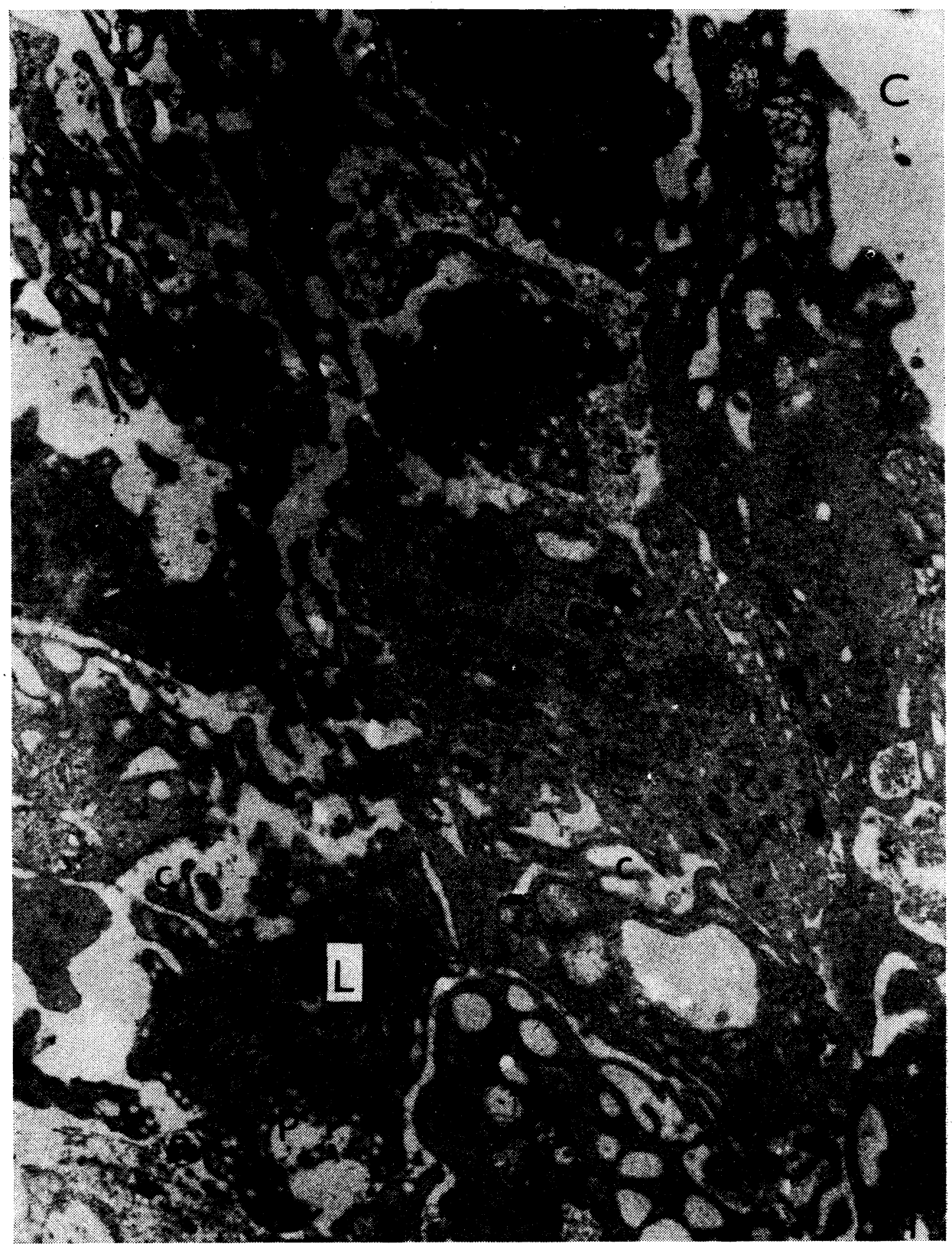

Fig. 1

Normal synovial membrane. Evident is the arrangement of several layers of cells A (A) separated by slits. In the intercellular spaces the synovial matrix (s). Ih the cytoplasm besides other organellae expressive lysosomes (L), pinocytotic vesicles (p). The cytoplasm projects into numerous filopodia (c). Joint cavity (C). Magnification: $16700 \times$. 


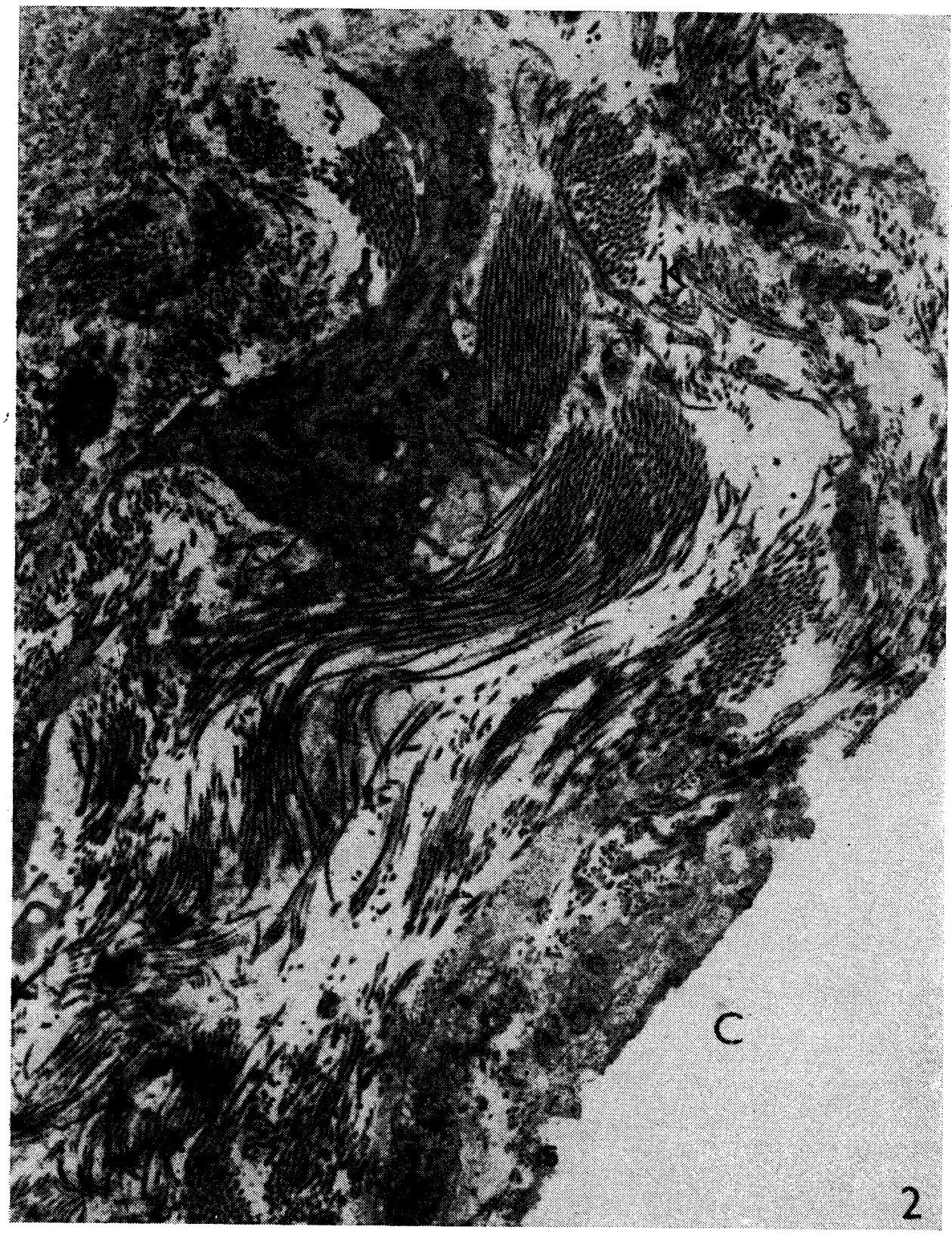

Fig. 2

Surface of a normal synovial membrane covered by a layer of matrix (s) with collagen fibres (K) sometimes even penetrating to the surface. The matrix is in contact with the joint cavity (C). Magnification: $16000 \times$. 


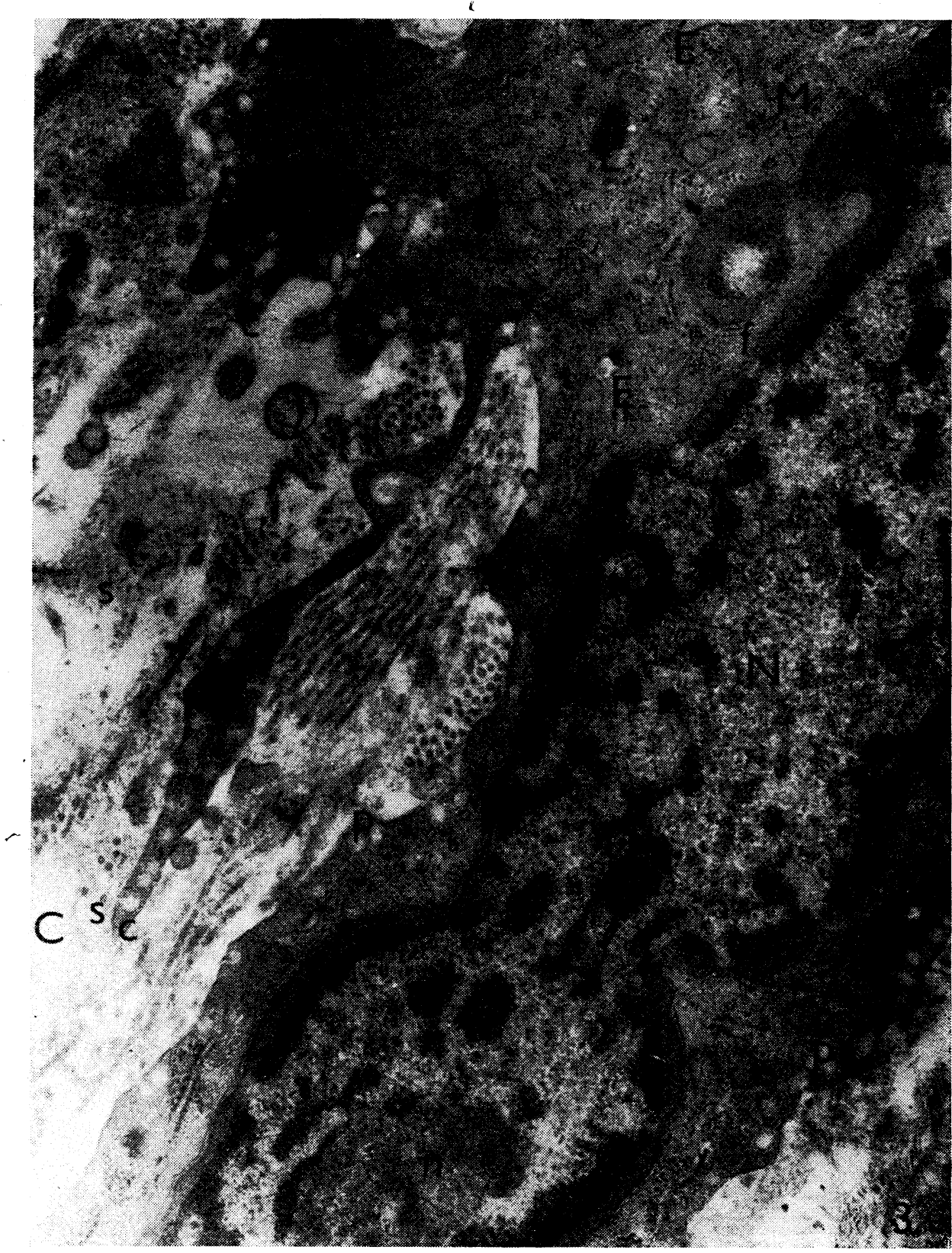

Fig. 3

Part of an A cell of a normal synovial membrane. Nucleus (N), nucleolus ( $n$ ), zonula nucleum limitans (z), innumerous cisternae of the granular endoplasmic reticulum (E) with content, mitochondria (M), lysosomes (L), cytoplasmic filaments (f), cytoplasmic processes (c), pinocytotic vesicles (p). Synovial matrix (s) is in contact with the joint cavity (C). Magnification: $29400 \times$. 
1973, Crey and Cohen 1973, Ghadially et al. 1974, Klein 1974, Maldyk et al. 1974, Watanabe et al. 1974, Krey et al. 1976), whereas e. g. in rats the matrix is considerably reduced and the cells are closely attached to each other (Roy and Ghadially 1967, Wassilev 1972, 1973, 1975). As far as the arrangement of cells of the synovial membrane is concerned the author's findings are in accordance with data of Lever and Ford (1958) who were the first to observe parts of the synovial membrane uncovered by a continuous layer of cells (Fig. 2). The matrix thus comes into direct contact with the synovial fluid. This finding was negated by Barland et al. (1962); however, later studies (Rayns and Highton 1966, Roy 1966, Roy et al. 1966, Ghadially and Roy 1967b, 1969, Bozděch et al. 1973, Klein 1974, Maldyk et al. 1974, Oryschak et al. 1976) and others confirmed this fact.

The ultrastructure of A cells

Cells of the A type are predominating elements in the cellular population of the synovial membrane. They occur both near the surface and in the deeper layers.

\section{a) Nucleus (Fig. 3)}

The A type cells contain one nucleus of a rounded or spindle-like elongated shape. The nuclear envelope has the usual structure and in contradistinction to the karyoplasm it projects in the form of shallow invaginations. Such a nucleus was described by Barland et al. (1962), Roy (1966), Roy et al. (1966), Ghadially and Roy (1967b, 1969), Bozděch et al. (1973), Huth et al. (1973), Ghadially et al. (1974), Klein (1974), Oryschak et al. (1976a). A continuous strip of finely granulated, moderately osmiophil substance adheres to the inner membrane of a thickness of as much as $0.1 \mu \mathrm{m}$, indicated as zonula nucleum limitans. This layer deposited between the inner membrane of the nuclear envelope and chromatin was also proved by Roy et al. (1966) Ghadially and Roy (1976 b, 1969a), Bozděch et al. (1973) and others. Ghadially et al. (1974) and Oryschak et al. (1976b) dealt with changes of its thickness in cells of the synovial membrane with diseases of the joint.

The nuclear chromatin as arranged on the section by the nucleus into karyosomes of various size which press onto the zonula nucleum limitans and form a virtually continuous layer interrupted only in the places of nuclear pores. The nucleolus occurs regularly in the nucleus of A cells of the synovial membrane. In all cases reticular nucleoles were observed.

b) Cytoplasm (Figs. 3, 4)

a) cell organellae

Granular endoplasmic reticulum occurs in the cytoplasm of A cells of the synovial membrane in the form of infrequent flattened cisternae or sacs to the surface of which ribosomes are attached. Its structures are located irregularly in the cytoplasm, no larger accumulation in the form of parallel running cisternae was found. The spaces of the granular endoplasmic reticulum are generally filled up with a moderately osmiophil, finely granular material. The author's observations are in accordance with literary data, especially with the studies of 


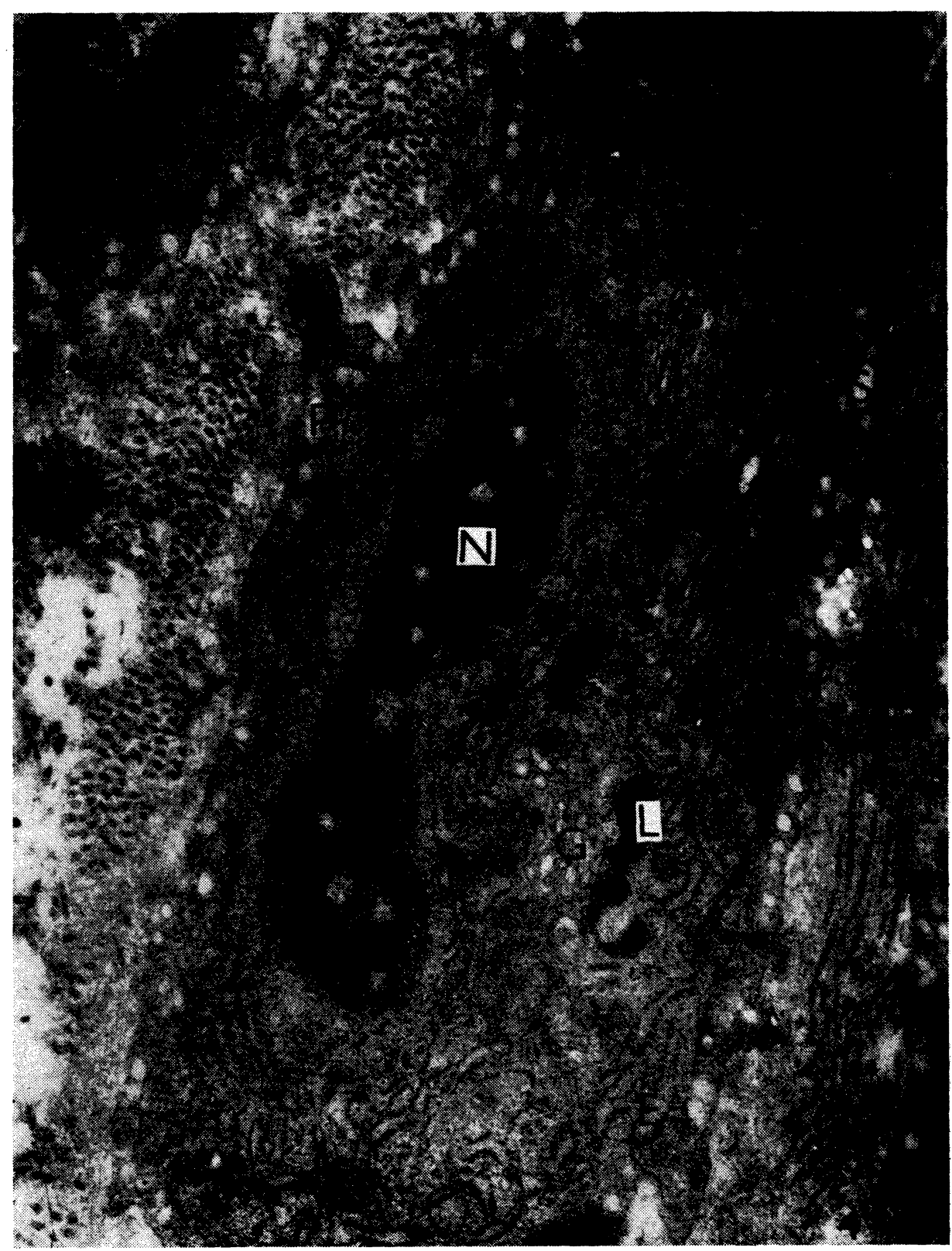

Fig. 4

Part of the cytoplasm and nucleus of an A cells of a normal synovial membrane. Nucleus (N), zonula nucleum limitans (z), cisternae of the granular endoplasmic reticulum (E) with content, agranular endoplasmic reticulum (S), Golgi complex (G), mitochondria (M), lysosomes (L), cytoplasmic filaments (f), pinocytotic vesicles (p.) Magnification: $29400 \times$. 
Barland et al. (1962), Roy (1966), Roy et al. (1966), Ghadially and Roy (1967b, 1969a), Bozděch et al. (1973) and others.

Agranular endoplasmic reticulum occurs in the cytoplasm of A cells in the form of minute sacs splitting off from the cisternae of the Golgi complex. It can, however, originate from the pinocytotic vesicles passing into the cytoplasm at various distances (Figs. 3, 4).

The Golgi complex has its usual structure and in the cytoplasm of A cells is spread into $1-3$ fields (Fig. 4). Small and large vesicles passing into the surrounding cytoplasm separate from the club-like expanded smooth cisternae of the Golgi complex. These vesicles represent the substantial part of the agranular endoplasmic reticulum in the cytoplasm of A cells. A finely granular, moderately osmiophil substance occurs frequently in the vesicles. According to literary data (Barland et al. 1962, Rayns and Highton 1966, Roy 1966, Roy et al. 1966, Ghadially and Roy 1967b, Huth et al. 1973, Klein 1974, Maldyk et al. 1974, Poole et al. 1976) the largely developed Golgi complex is one of the basic characteristics of A cells of the synovial membrane.

Mitochondria of the A cells are of a usual structure, on cross sections they reach the size of $0.1-0.5 \mu \mathrm{m}$. The mitochondrial matrix is dense so that the irregularly running leaf-like cristae can hardly be demonstrated. The mitochondrial corpuscles occur only sporadically (Figs. 3, 4). The results of the author's studies are in accordance with data of Barland et al. (1962), Roy (1966), Roy et al. (1966), Ghadially and Roy (1967b, 1969), Maldyk et al. (1974) and others as far as the human synovial membrane is concerned. Mitochondria differing in their appearance and cristae arrangement occur in the synovial membrane of the rabbit and rat, as was described by Wyllie et al. (1964), Ghadially and Roy (1966), Roy and Ghadially (1967), Mitchell and Blackwell (1968), Cherney et al. (1970), Wassilev $(1972,1973,1975)$, Krey et al. (1976), Watanabe et al. (1976a, b).

Ribosomes, in their majority, are attached to the membranes of the granular endoplasmic reticulum, only rarely do they form polysomes (Figs. 3, 4). Literary data about them are only fragmentary so that results of the present studies could not be confronted.

Lysosomes in the cytoplasm of A cells are present in relatively large numbers. They are always secondary lysosomes, of a size of $0.1-1 \mu \mathrm{m}$ and more (Fig. 4). They are contoured by a simple membrane and they contain either electron dense, homogeneous material, or granular material. In some cases they contain, besides granular material, also membranous structures originating probably from mitochondria. The frequent occurrence of secondary lysosomes in the cytoplasm of A cells of the synovial membrane was one of the causes why many authors considered this type of cells to be capable of phagocytosis (Ball et al. 1964, Cochrane et al. 1965, Adam 1966, Muirden 1966, Ghadially and Roy 1967, Luckenbill and Cohen 1967, Muirden and Senator 1968, Webb et al. 1969, Bhawan et al. 1973, Wassilev 1972, 1975, Bhawan and Roy 1974, Cchiu 1975, Biro 1974, Krey et al. 1974, Johansson and Rejnö 1976, Oryschak and Ghadially 1976a) and others.

Centrioles occur in the cytoplasm of this cellular type only very sporadically. In available literature their occurrence has been mentioned only by Ghadially and Roy (1969a), the other authors, as well as the author of this study, did not find centrioles. 


\section{$\beta$ ) cytoplasmic inclusions}

Lipid droplets and glycogen are generally a very rare finding in the cytoplasm of A cells of a normal synovial membrane. Glycogen can occur in the form or individual granules dispersed in the cytoplasm. They never form deposits or rosette-like formations as e. g. in the liver cells or in the cartilage. In the present material these inclusions were found only very exceptionally and this is completely in accordance with literary data.

Cytoplasmic fibrillar structures are represented by filaments of a thickness of $3-5 \mathrm{~nm}$ and they regularly occur in variable amounts in the cytoplasm of A cells. Most frequently they are deposited perinuclearly and they run in small bundles. They can also occur on the periphery of the cytoplasm between cellular organellae where they are probably extruded into the intercellular space and thus become part of the synovial matrix (Fig. 3).

\section{$\gamma)$ cell surface}

The cytoplasm of A cells projects in numerous processes covered by a cellular membrane. Some of them run only shortly, others are long even several $\mu \mathrm{m}$ (Figs. 3, 4). Characteristic for the cellular surface of A cells is the great number of pinocytotic vesicles often filled up with material of the same appearance as on the surrounding synovial matrix (Fig. 4). The articulated surface with many filopodia of various length and numerous pinocytotic vesicles is characteristic for cells of the A type as was mentioned namely by Barland et al. (1962), Roy (1966), Roy et al. (1966), Ghadially and Roy (1967b, 1969), Bozděch et al. (1973), Huth et al. (1973), Klein (1974) and others when describing human synovial membrane, and Wyllie et al. (1964), Ghadially and Roy (1966), Roy and Ghadially (1967), Mitchell and Blackwell (1968), Muirden and Peace (1969), Cherney et al. (1970), Wassilev (1972, 1973, 1975), Krey and Cohen (1973), Howlett (1974), Watanabe et al. (1974, 1976a, b), Johansson and Rejnö (1976), Krey et al. (1976), Oryschak and Ghadially (1976a) and others, in the synovial membrane of lower mammals.

Desmosomes do not occur among the cells of the human synovial membrane. They were found only in the synovial membrane of the rat (Roy and Ghadially 1967, Wassilev 1972, 1975).

\section{The ultrastructure of B cells}

In comparison with the A cells they are represented in the cellular population of the synovial membrane much less frequently. They can be deposited either near the surface or, less frequently, in the deeper layers of the synovial membrane. Their shape on the section is most often polygonal or elongated in a cylinder-like way (Figs. 5, 6).

\section{a) Nucleus (Fig. 5)}

In contradistinction to the nucleus of the A type cell it is usually of an oval shape and in the cytoplasm is deposited expressively excentrically. The structure of the nuclear envelope is usual and protrudes against the karyoplasm in only quite shallow sporadic folds. The zonula nucleum limitans adheres to the inner membrane of the nuclear envelope and has the same appearance, arrangement and thickness as in the nuclei of the A cells. 


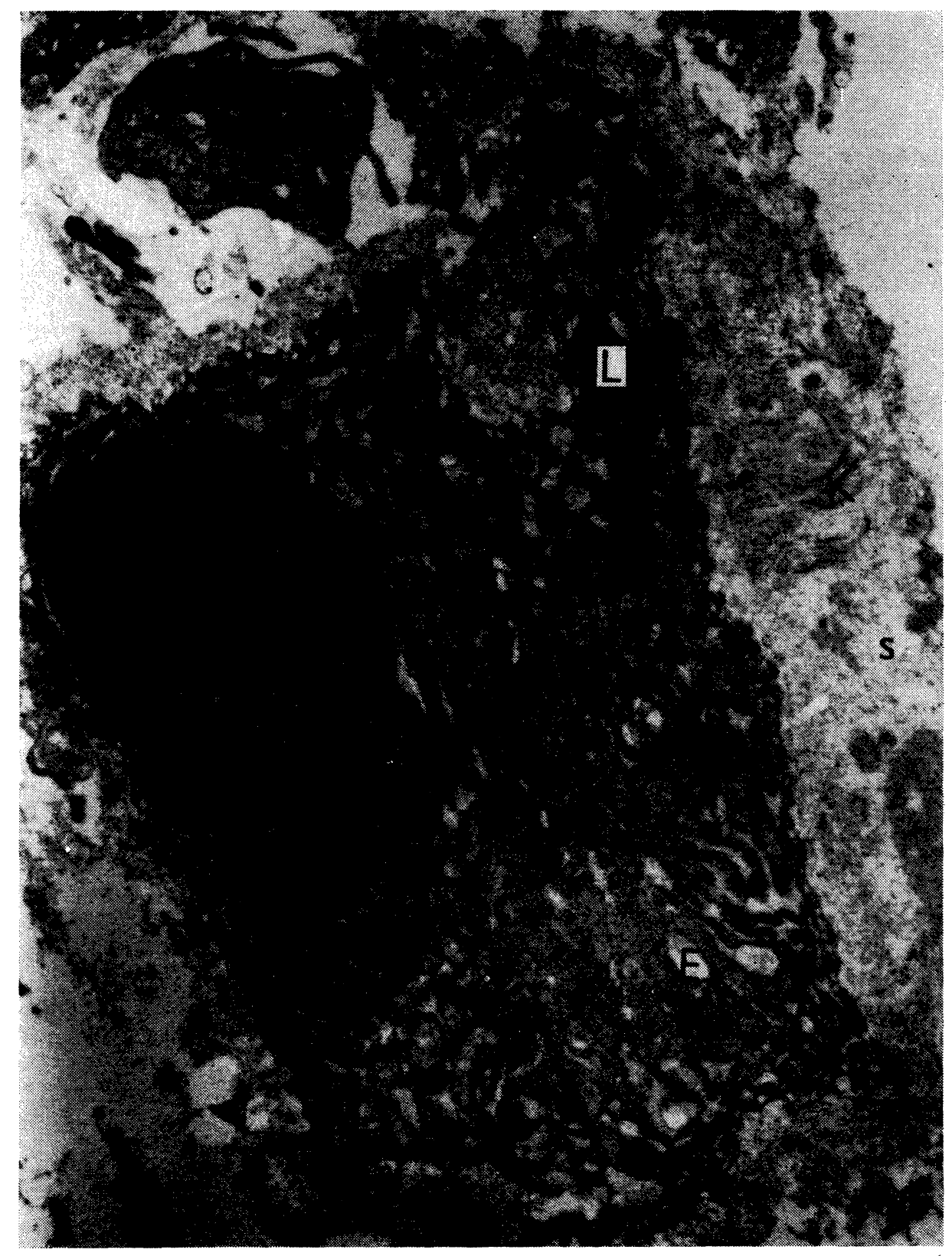

Fig. 5

The B cell of a normal synovial membrane. Nucleus $(\mathrm{N})$, nucleolus ( $\mathrm{n}$ ), zonula nucleum limitans (z), dilated cisternae of the granular endoplasmic reticulum (E) with granular content. Golgi complex (G), mitochondria (M), lysosomes (L). Collagen fibres (K) in matrix (s). Magnification: 


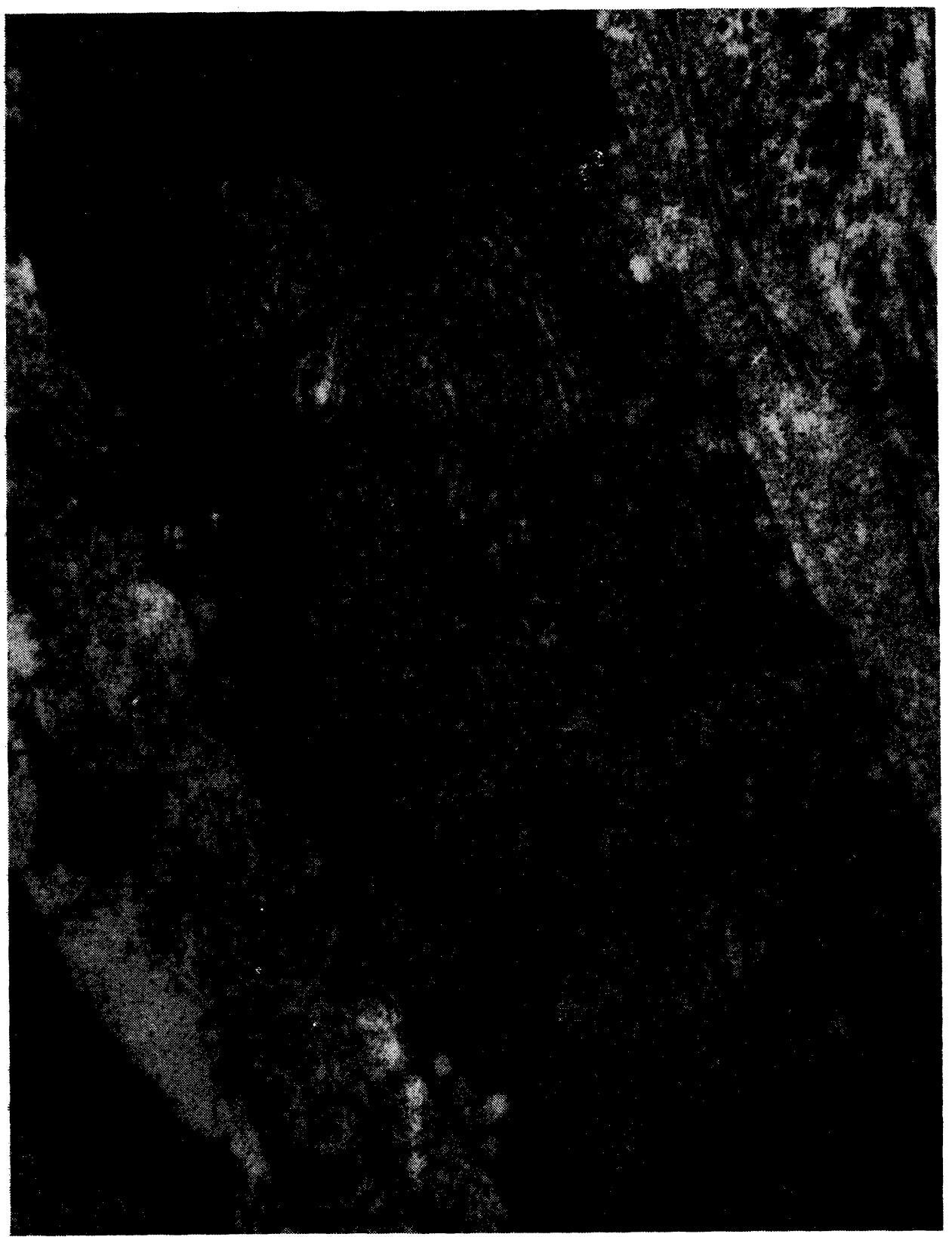

Fig. 6

Part of cytoplasm of a B cell of a normal synovial membrane with flattened cisternae of granular . endoplasmic reticulum (E) filled up with finely granular material. Golgi complex (G), mitochondria (M), lysosomes (1), cytoplasmic filaments (f), pinocytotic vesicles (p). In the matrix collagen fibres (K) and aperiodic fibres (a). Magnification: $43900 \times$. 
In contradistinction to the nuclei of A cells perichromatin granules occur in the chromatin of B cells.

In number, size and appearance the nucleolus does not differ from the nucleolus. of A cells of the synovial membrane.

b) cytoplasm (Figs. 5, 6)

In semiquantitative estimations it is evident that the cytoplasm has a larger volume as compared with the A cells.

$\alpha)$ cell organellae

Granular endoplasmic reticulum was found in the cytoplasm of B cells in strikingly large numbers as compared with the A cells. On the sections only its two arrangements are evident. In the first case it resembles relatively widely dilated cisternae and sacs the largest amount of which is deposited on the cell periphery, whereas the region above the nucleus contains only a small amount: of these cisternae. In their majority the cisternae are filled up with osmiophil, finely granular even fibrillary substance (Fig. 5). In the other case the numerous cisternae are again found on the periphery of the cell, however, they are flattened and relatively densely accumulated (Fig. 6). The author's observations concerning the frequency of occurrence of cisternae of the granular endoplasmic reticulum in the cytoplasm of B cells are in accordance with the observations of Barland et al. (1962), Muirden (1966), Roy (1966), Roy et al. (1966), Ghadially and Roy (1967b, 1969), Huth et al. (1973), Bozděch et al. (1973), Klein (1974), Maldyk et al. (1974), Poole (1976) and others.

Agranular endoplasmic reticulum occurs in the cytoplasm of B cells in the form of scarce smooth vesicles, localized mostly near the Golgi complex from which they most probably originate.

Golgi complex is an inexpressive structure in the cytoplasm of B cells with dilated cisternae of granular endoplasmic reticulum. It is formed by 3-4 short, flattened cisternae and small vesicles. It is usually localized in the zone above the nucleus and is spread into several small fields (Fig. 5). Some of the larger vesicles are filled up with a fine, moderately osmiophil material. The results of the author's observations on the arrangement and frequency of occurrence of the Golgi complex in the cytoplasm of B cells differ, to a certain extent, from literary data, namely in that he proved the Golgi complex in B cells in"all the cases and, in addition, spread into several, even though small fields (Fig. 6), whereas the studies published earlier, e. g. Barland et al. (1962), Roy et al. (1966), Ghadially and Roy $(1967 \mathrm{~b}, 1969)$ state that the structures of the Golgi complex are difficult to demonstrate.

Mitochondria of the B cells do not differ from cells of the A type in their dimensions, localization and number (Fig. 6).

Ribosomes, in their majority, are bound to the membranes of the granular endoplasmic reticulum. They occur freely in the cytoplasm either individually or in the form of polysomes only in the zone above the nucleus near the Golgi complex.

Lysosomes in the cytoplasm of B cells are less frequent as compared with A cells. Provided they are found on the sections they appear as corpuscles contoured by a simple membrane of a size of $0.1-0.5 \mu \mathrm{m}$. On the one hand, they contain granular, electron-dense material, and on the other hand, a very dark, homogenous substance and small vacuoles which are electron optically empty 
(Figs. 5, 6). The author's observations are in accordance with data published by Barland et al. (1962), Roy (1966), Roy et al. (1966), Ghadially and Roy (1967b, 1969), Bozděch et al. (1973) on the organellae in a normal human synovial membrane and by Ball et al. (1964), Cochrane et al. (1965), Adam (1966), Ghadially and Roy (1967), Webb et al. (1969), Cchiu (1975) in the synovial membrane of various mammals and by Oryschak and Ghadially (1976a) after experimental treatment of the rabbit joint.

Microtubules and centrioles were not proved in the author's material and have not been stated in literature.

$\beta$ ) cytoplasmic inclusions

Lipid droplets and glycogen were found only very exceptionally in the cytoplasm of B cells of a normal synovial membrane both human and of lower mammals. In the author's material they were not proved.

Cytoplasmic fibrillar structures have the same appearance and size as in the cytoplasm of A cells. The only difference is their amount. In the B cells they occur in small bundles only sporadically and are usually deposited mostly on the periphery of the cytoplasm (Fig. 6).

\section{$\gamma)$ cell surface}

The cytoplasm of B cells projects only in a small number of short, not ramifying projections and in some places only do we find larger folds of cellular membrane penetrating deeply into the cytoplasm (Fig. 5). The frequency of pinocytotic vesicles is the same as in cells of the A type. They are filled up with a substance which is morphologically identical with the surrounding matrix.

\section{Synovial matrix}

This term is commonly used to indicate the intercellular substance of the synovial membrane which consists of the ground fibrillar substance and the ground amorphous substance similarly as in other tissues originating from the mesenchyme. In literature only minimum attention was paid to this component of the synovial membrane, even though many authors do mention it (e. g. Barland et al. 1962, Muirden 1966, Roy 1966, Roy et al. 1966, Ghadially and Roy 1967, Bozděch et al. 1973, Ghadially et al. 1974). More detailed data were published by Ghadially and Roy (1969), however, they only dealt with the arrangement of the fibrillar component in a one-layered and multi-layered synovial membrane.

Ground fibrillar substance is formed of two types of fibrillar structures. In the first place they are typical collagen fibres of a width of $60-100 \mathrm{~nm}$ and length of as much as several $\mu \mathrm{m}$, only sporadically ramifying and showing a periodicity characteristic for collagen fibres, i. e. about $64 \mathrm{~nm}$ (Fig. 2). The other type of fibrillar structure are aperiodic fibres of a width of about $50 \mathrm{~nm}$ and length of $0,1 \mu \mathrm{m}$, even more rarely. These fibres occur in dilated cisternae of the granular endoplasmic reticulum, in the ground cytoplasm among the cell organellae and perinuclearly mainly in cells of the A type (Figs. 3,6). Fibrillar structures of such an appearance were described by Ghadially and Roy (1969a), Huth et al. (1973), Ghadially et al. (1974), Klein (1974) in cells of the human synovial membrane, by Wyllie et al. (1964), Ghadially and Roy (1966), Roy and Ghadially (1967), Mitchell and Blackwell (1968), Cherney et al (1970), 


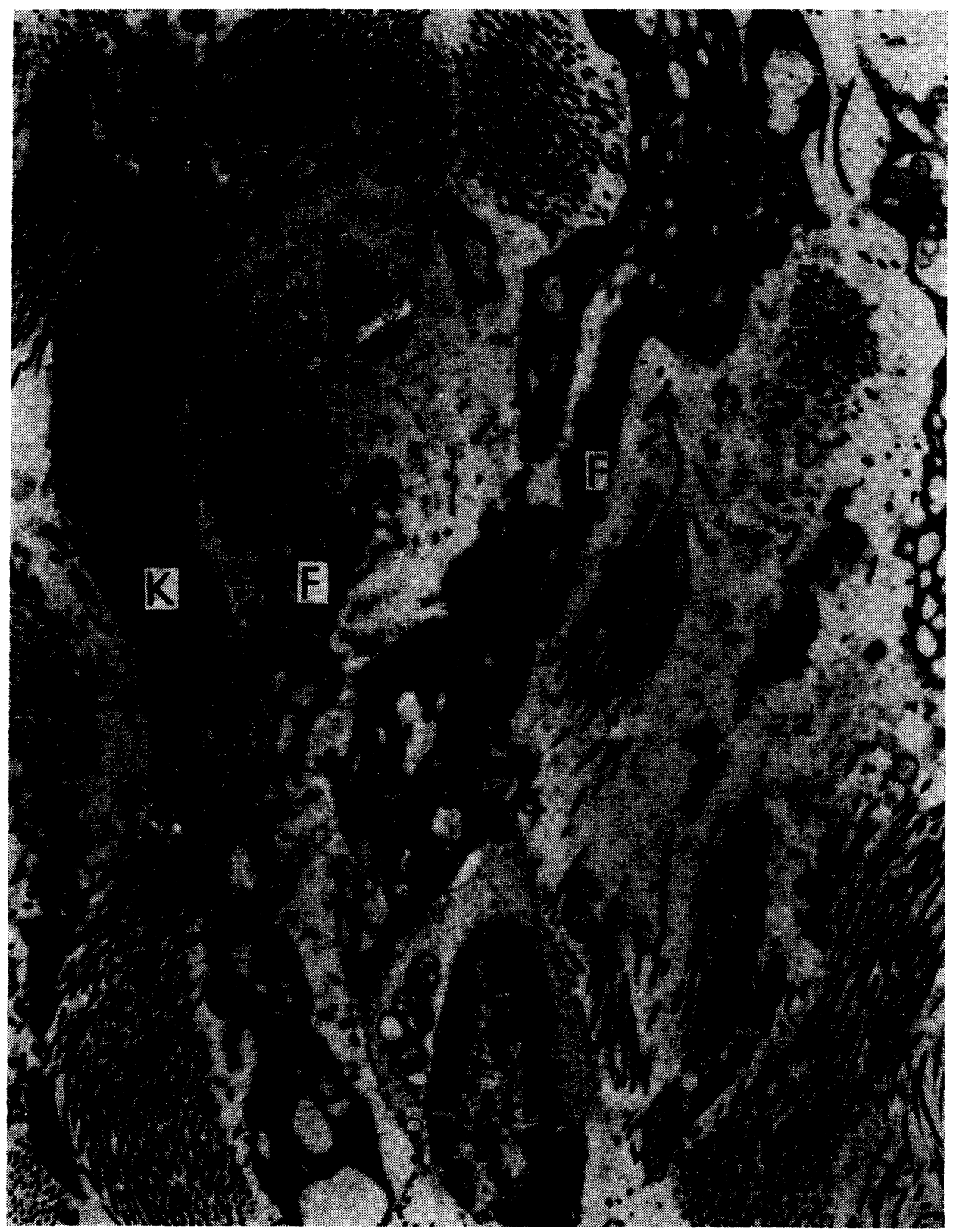

Fig. 7

Subsynovial tissue with longitudinally and transversely oriented bundles of collagen fibres $(\mathrm{K})$, ground amorphous substance (za) and numerous filopodia of fibrocytes (F). Magnification: $12800 \times$. 
Wassilev (1972, 1975), Krey and Cohen (1973), Watanabe (1974) in cells of the synovial membrane of lower mammals.

Ground amorphous substance, into which the fibrillar component is inserted, is formed similarly as in other types of tissue mainly by a complex of protein-hyaluronic acid and sulphonated mucopolysaccharides. In an electron microscope both types of substances are shown as a finely granular, moderately osmiophil substance, deposited in the spaces between the collagen fibres (Fig. 7). It seems probable that both components, i. e. both the protein-hyaluronic acid complex and mucopolysaccharides migrate into the synovial fluid (Ghadially and Roy 1969).

The arrangement of the intercellular substance, mainly as far as the ground fibrillar substance is concerned, differs, on the one hand, in its direction from the surface into the deeper layers of the synovial membrane, on the other hand, is dependent on the amount and arrangement of the synovial cells.

In those parts of the synovial membrane where the cells are deposited in several layers the margin between the synovial membrane and the joint cavity is formed only by synovial cells which are not covered by an intercellular substance. The intercellular substance can communicate with the joint cavity only in short segments (Fig. 1). The situation is different in those cases when the cells of the synovial membrane are deposited on the surface only in one layer. In these parts the cells usually do not reach to the surface of the membrane and are covered over with a layer of intercellular substance of various thickness consisting mainly of aperiodic fibrils connected together with the amorphous component which is shown in the form of more compact, granular parts (Fig. 2). The typical collagen fibres occur in the superficial layer only in very small numbers.

Under such a formed surface, both in the middle and deep layers, in the case of a layered synovial membrane completely predominating are typical collagen fibres, often arranged into bundles above the aperiodic fibrils. Among the bundles of collagen fibres there is a small amount of the ground amorphous substance. This mutual representation of the ground fibrillar and amorphous substances in the human synovial membrane somewhat differs when compared with lower mammals where the amorphous substance can be identified in the form of small clusters only in the middle zone, whereas in the deep layer there is practically none at all (W yllie et al. 1964, Ghadially and Roy 1966, Roy and Ghadially 1967, Wassilev 1972, 1975, Krey 1973, Watanabe 1974).

\section{Submicroscopic structure of subsynovial tissue}

The structure of the subsynovial tissue differs even within the same joint due to the various quantitative representation of the cells and of the ground fibrillar and amorphous substances. According to these criteria it used to be classified as fibrous, fibrous lipid and lipid subsynovial tissue. At the present time, on the basis of new knowledge, it is divided into two types, $i$. e. fibrous and lipid (J affe 1972). With regard to the fact that no basal membrane has been proved in the human synovial membrane separating the cells of the synovial membrane from the structures deposited lower (Barland et al. 1962, Coulter 1962, Rayns and Highton 1966, Roy 1966, Roy et al. 1966, Ghadially and Roy 1967b, Bozděch and Horn 1970, Bozděch et al. 1973, Huth et al. 1973, Klein 1974, Krey et al. 1974, Maldyk et al. 1974, and others) the dividing line between the synovial membrane proper and the subsynovial tissue is indistinct. The deep layer of the synovial membrane with no 
distinct contour passes into the subsynovial tissue. The real dividing line between the two layers is considered to be the region where, under the $\mathrm{A}$ and/or $\mathrm{B}$ cells of the synovial membrane, typical fibrocytes and/or macrophages are deposited more or less parallel with the surface; in the normal synovial membrane there are also sporadic mast cells (Fig. 7).

The ground fibrillar substance is represented by enormous bundles of collagen fibres with a typical periodicity, running in various directions, so that they can be found both on the transversal and tangential as well as cross sections. No aperiodic fibres were proved (Fig. 7).

Among the bundles of collagen fibres there is a variable amount of the ground amorphous substance. In an electron microscope it has its normal appearance of irregularly arranged network of medium electron density. Its amount is dependent on the frequency of collagen fibres and their arrangement into bundles.

\section{Appearance of the synovial membrane in a scanning electron microscope}

The structure of the normal synovial membrane was not studied in such detail in the scanning electron microscope as e. g. the joint cartilage. Many data were published about its appearance in various pathological processes, especially in arthrosis and rheumatic arthritis. The main reason is the fact that, in this case, the scanning electron microscopy did not meet the expectations as far as the contribution of new knowledge is concerned. In this respect it has by far been exceeded by transmission electron microscopy.

Under general enlargement the synovial membrane in the scanning electron microscope has the appearance of a clotted frilled tissue. The surface of the individual folds is not smooth, numerous parallelly running protuberances can be observed. The irregularities are due to the various thickness of the mucopolysaccharide layer adhering to the surface of the folds (Fig. 8). Attached to the surface are, on the one hand, free cells from the joint fluid, on the other hand, the cellular detritus and thick fibres which could, according to the author's opinion, have originated arteficially during the elaboration of the material by precipitation of hyaluronic acid in the course of fixation. Such an appearance of the synovial membrane was described by Fujita et al. (1968), Gryfe et al. (1969), Redler and Zimny (1970), Wysocki and Brinkhous (1972), Cameron and Macnab (1973), Gaucher et al. (1976), and others.

After removing the mucus with hyaluronidase the picture of the surface of the synovial membrane considerably differs. The view of the superficial layer proper of the synovial membrane is accessible and even under a general enlargement its much more complex structure is evident, even though in some parts remains of mucus can be seen in the form of rag-like shreds of a membrane shape. In the depressions between the frills formations looking like thick fibres often partitioning the notches occur. Similar connections with bundles of the same appearance can be observed in some cases also near the surface between the individual clots. On the bottom of the notches and on the lateral sides of the clots parallelly running lines are evident probably due to bundles of collagen fibres deposited deeply in the synovialis, which corresponds with observations done using a transmission electron microscope.

Under greater enlargement the very irregular surface of the synovial membrane can be distinctly seen. It is articulated by more or less parallelly running protuberances the height of which reaches as much as $0.2 \mathrm{~mm}$ and the lower ones de- 


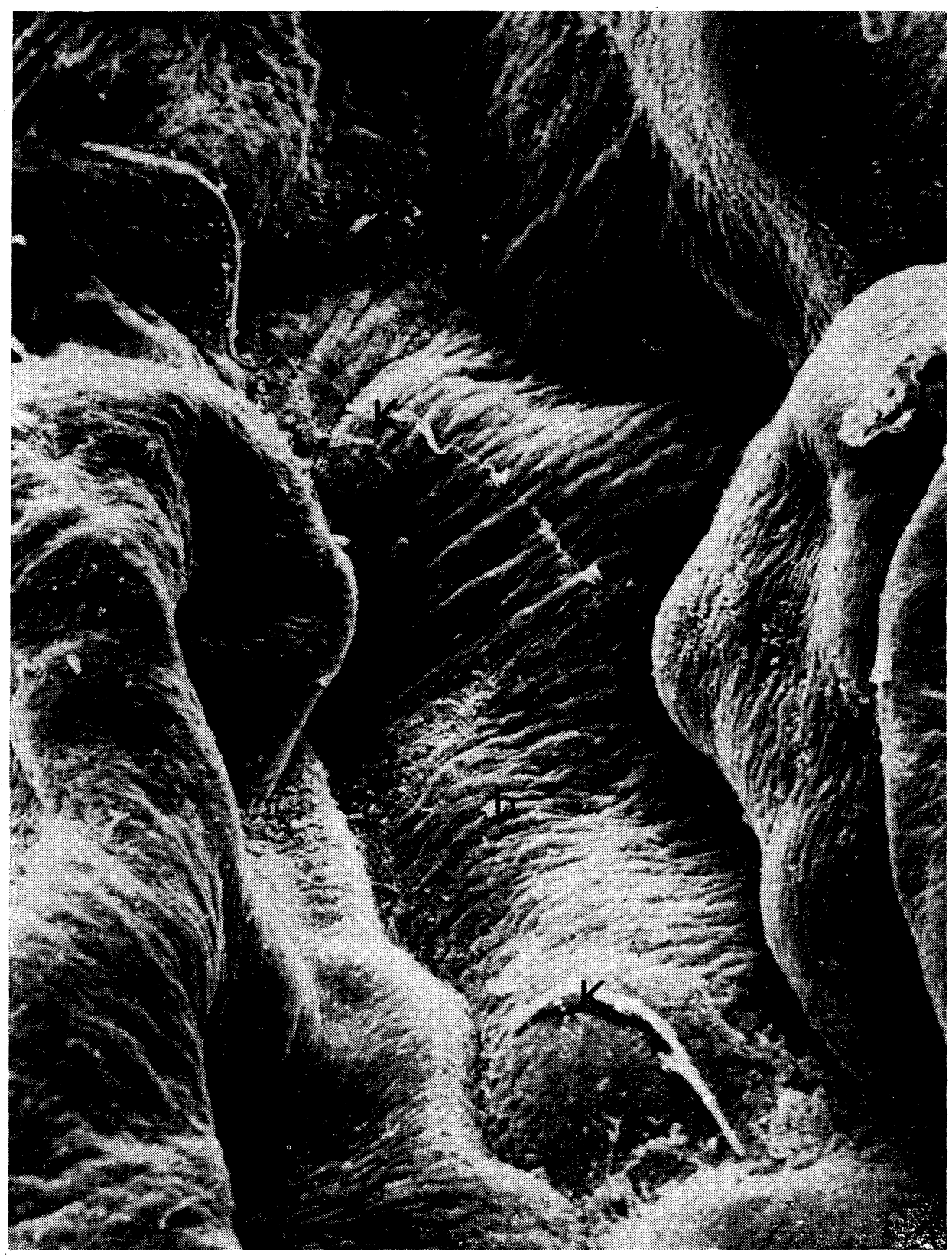

Fig. 8

Clotted frilled normal synovial membrane with wrinkled surface covered with a layer of mucopolysaccharides. Bundles of collagen fibres $(K)$ are attached to it and sporadic cells (b) and cellular detritus (d). Scanning electron microscopy. Magnification: $340 \times$. 


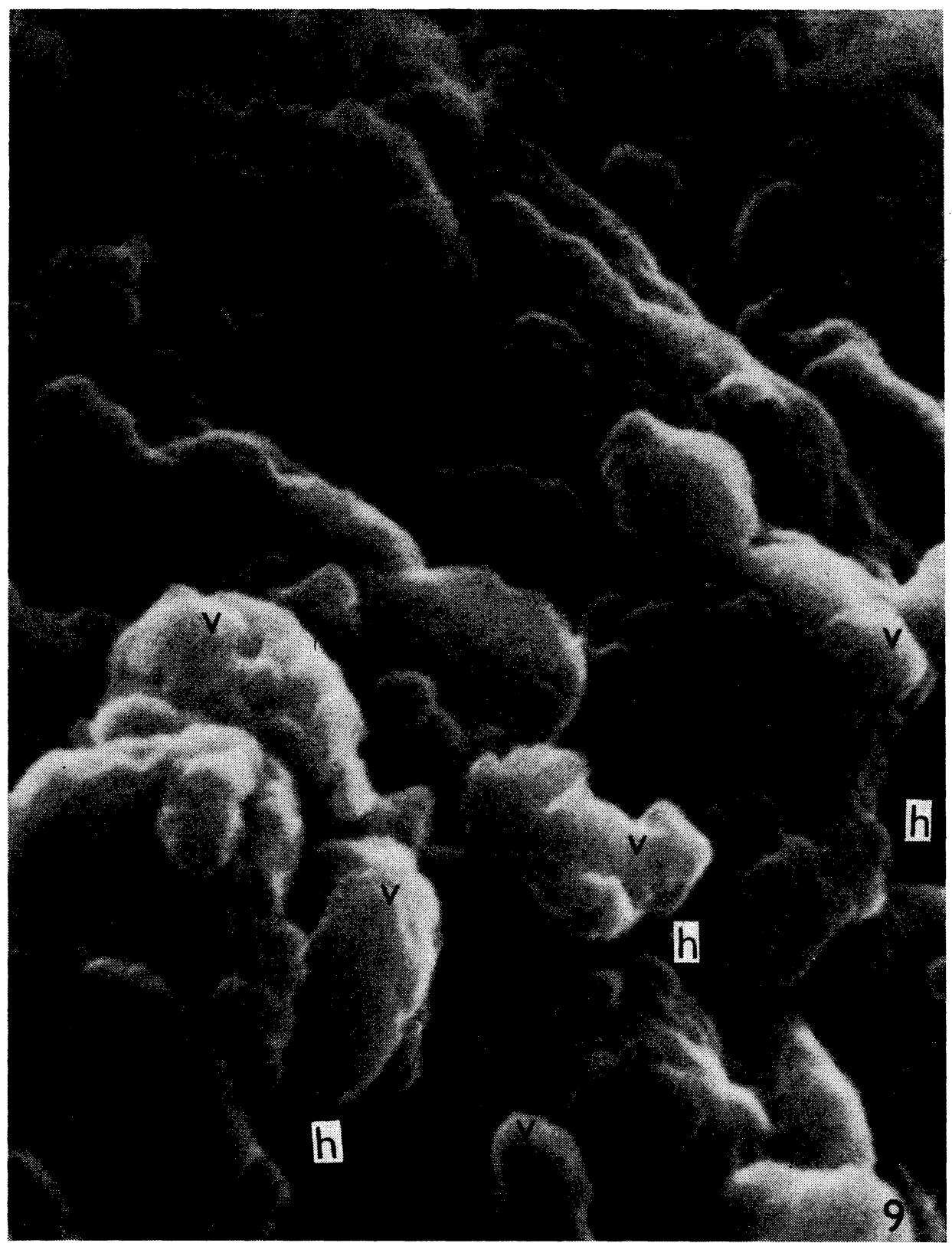

Fig. 9

Part of the surface of the clot of a normal synovial membrane under great enlargement. Papillary projections ( $v$ ) ar a due to parts of cells of the synovial membrane with depressions between them (h). Scanning electron microscopy. Magnification: $28700 \times$. 


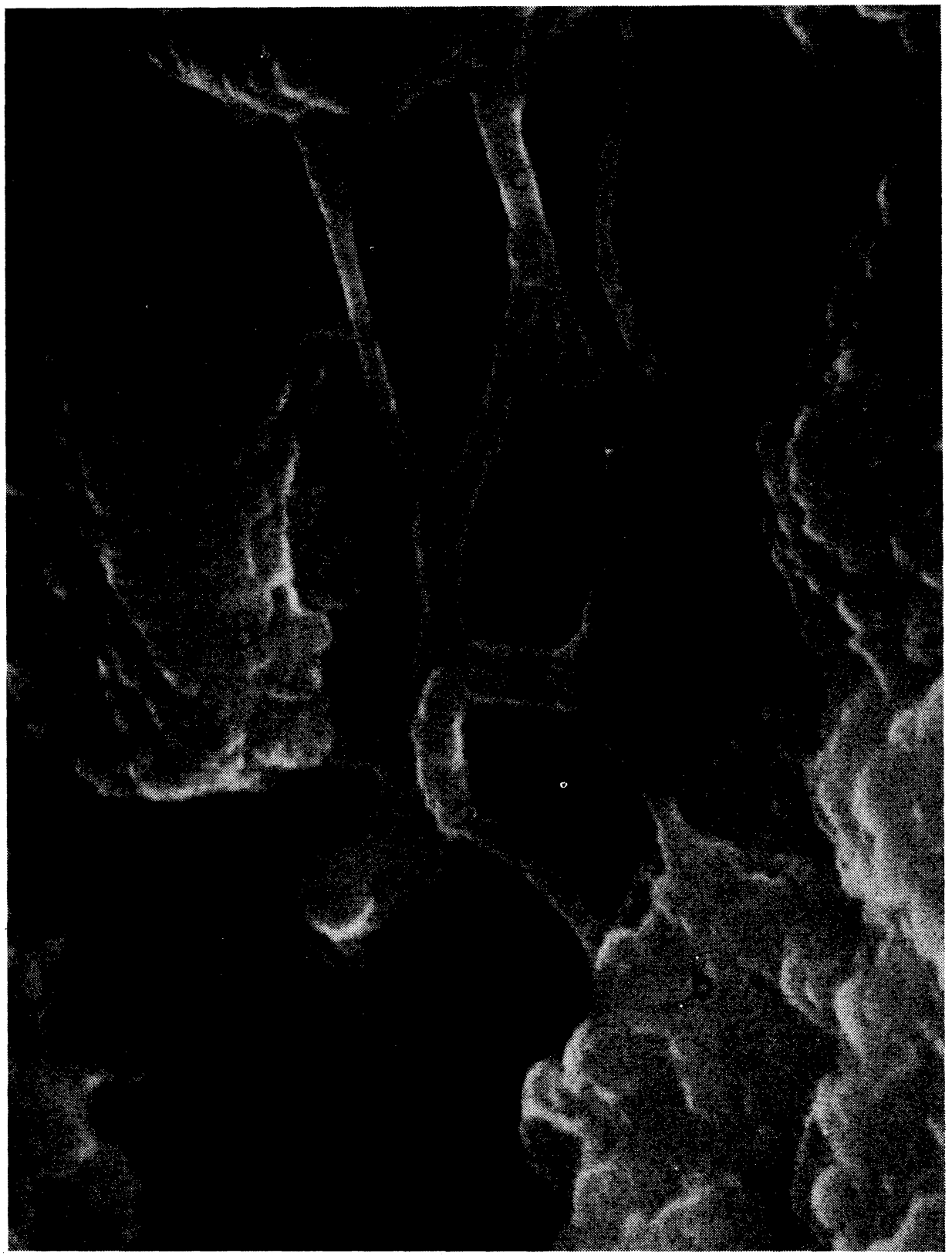

Fig. 10

Dilated intercellular spaces of the normal synovial membrane are separated by projections (c) of cells (b) and they touch each other. Scanning electron microscopy. Magnification: $25200 \times$. 
posited between them reach about half this height. Between these ridge-like lines variously formed and high papillary projections protuberate above the synovialis surface, reaching the height of the high ridges. The basis of the large ridge-like lines is probabily the frilled surface of the synovial membrane because they are evident als o on the synovial membrane covered by a mucous layer. The $0.1 \mathrm{~mm}$ high protuberances are most probably evoked by the collagen fibres protruding above the surface of the synovial membrane. Of the same origin are also the felt-like arranged fibres evident on the surface. The processes of the shape of papillae are due to the cells of the synovial membrane which can be seen on the surface under greater enlargement when both the cells proper and their cytoplasmic processes are evident (Fig. 9). Between the cells there appear free spaces resembling canals, described in the transmission electron microscope by Barland et al. (1962). As yet we cannot explain this finding, similarly as Redlet and Zimny (1970) because in the author's material they did not appear in the transmission electron microscope and they have not been described in literature. They are probably dilated intercellular spaces where part of the intercellular substance disappeared, because in detailed studies of these depressions it was found that they are partitioned by processes of synovial cells mutually attached and thus forming net-like formations (Fig. 10). The results of the present study in this respect cannot, unfortunately, be compared with literary data as no similar findings were found in the studies of the authors mentioned above.

\section{Submikroskopická struktura synoviální membrány člověka}

V práci byla popsána ultrastruktura buněk synoviální membrány, složení mezibuněčné hmoty a vzhled synoviální membrány v rastrovacím elektronovém mikroskopu 38 jedinců stáří $12-67$ let. Synoviální membrána se skládá ze specificky modifikovaných buněk, které na podkladě studia jejich submikroskopické stavby můžeme diferencovat na $\mathrm{A}$ a $\mathrm{B}$ typ a $\mathrm{z}$ hmoty mezibuněčné. Pod vlastní synoviální membránou je uložena subsynoviální tkáň. Povrch synoviální membrány je tvořen jednou až čtyřmi vrstvami buněk. $\mathrm{V}$ buněčné populaci převažují $\mathrm{A}$ buňky, zatímco buňky typu $B$ jsou početně méně zastoupeny. Krátké úseky synoviální membrány jsou kryty pouze mezibuněčnou hmotou, která je tak $\mathrm{v}$ přímém kontaktu s dutinou kloubní. Buněk typu $B$ je $\mathrm{v}$ normální synoviální membráně malý počet. Jsou uloženy převážně $\mathrm{v}$ blízkosti povrchu synovialis. Kromě buněk $\mathrm{A}$ a $\mathrm{B}$ se $\mathrm{v}$ lidské synoviální membráně vyskytuje proměnlivé množství přechodných buněčných forem, které mají některé společné znaky obou vyhraněných typů. Jejich výskyt je vázán na fyziologický stav kloubu. Základní hmota vláknitá je tvořena fibrilárními strukturami dvojího vzhledu. Jednak jsou to kolagenní vlákna šírky 60 až $100 \mathrm{~nm}$ a délky až několika $\mu \mathrm{m}$ s periodicitou $64 \mathrm{~nm}$, jednak aperiodická vlákna šířky kolem $50 \mathrm{~nm}$ a délky průměrně $0,1 \mu \mathrm{m}$. Základní hmota amorfní, do níž je vložena složka vláknitá, je tvořena komplexem protein-kyselina hyaluronová a sulfonovanými mukopolysacharidy. Subsynoviální tkáň $\mathrm{v}$ našem materiálu má fibrosní vzhled. Mezibuněčná hmota je reprezentována mohutnými svazky kolagenních vláken, probíhajícími různými směry. Aperiodická vlákna chybějí. V rastrovacím elektronovém mikroskopu má synoviální membrána vzhled zřasené tkáně, na jejímž povrchu lze pozorovat vyvýšeniny oddělené zářezy. Vyvýšeniny jsou způsobeny jak buňkami a jejich výběžky, tak kolagenními vlákny, pronikajícími do povrchových vrstev synoviální membrány. 


\section{Субмикроскопическая структура синовиальной оболочки человека}

В работе дается описание ультраструктуры клеток синовиальной оболочки, состав межклеточной массы и вид синовиальной мембраны в растровом электронном микроскопе 38 человек в возрасте 12-67 лет. Синовиальная оболочка состоит из специфически приспособленных клеток, которые на основе исследования их субмикроскопической структуры можно разделить на $\mathrm{A}$ и В типы и межклеточную массу. Под собственной синовиальной оболочкой находится субсиновиальная ткань. Поверхность синовиальной оболочки образуют один - четыре слоя клеток. Преобладающими в клеточной популяции являются клетки $\mathrm{A}$, между тем как клетки типа $\mathrm{D}$ по численности представлены меньше. Короткие отрезки синовиальной оболочки покрыты лишь межклеточной массой, находящейся таким образом в непосредственном контакте с полостью сустава. В нормальной синовиальной оболочке клеток типа В имеется небольшое количество. Они уложены преимущественно в5лизи поверхности синовия. Помимо клеток $\mathrm{A}$ и $\mathrm{B}$ в синовиальной оболочке человека имеет место непостоянное количество временных клеточных форм, отличающихся некоторыми общими знаками обоих крайных типов. Их наличие связано с физиологическим состоянием сустава. Основная волокнистая масса образуется фибриллярными структурами двойного вида. Речь идет о коллагеновых волокнах шириной 60-100 нм и длиной несколько мкм с периоцичностью 64 нм, а также об апериодических волокнах шириной около 50 нм и длиной в среднем 0,1 мкм. Основная масса является аморфной, в которой входит волокнистый элемент, и образуется комплексом протеин - гиалуроновая кислота и сульфированными мукополисахаридами. Субсиновиальная ткань в нашем материале отличается фиброзным видом. Межклеточная масса представлена мощными пучками коллагенных волокон, проходящих в разном направлении. Непериодических волокон нет. Синовиальная оболочка в растровом әлектронном микрсскопе приобретает вид сборчатой ткани, на поверхности которой наблюдаются отделепные засечками бугорки. Бугорки образованы не только клетками и их выступами, но и коллагенными волокнами, проникаъщими в поверхностные слои синовиальной оболочки.

\section{References}

ADAM, W. S.: Fine structure of synovial membrane: phagocytosis of colloidal carbon from the joint cavity, Lab. Invest., 15, 1966: 680-691.

BALL, J. - CHAPMAN, J. A. - MUIRDEN, K. D.: The uptake of iron in rabbit synovial tissue following intraarticular injection of iron dextran. A light and electron microscope study. J. Cell Biol., 22, 1964: 355-364.

BARLAND, P. - NOVIKOFF, A. B. - HAMERMAN, D.: Electron microscopy of the human synovial membrane. J. Cell Biol., 14, 1962: 207-220.

BHAWAN, J. - TANDON, H. D. - ROY, S.: Ultrastructure of synovial membrane in pyogenic arthritis. Arch. Pathol., 96, 1973: 155-160.

BHAWAN, J. - ROY, S.: Ultrastructure of synovial membrane in pyogenic arthritis caused by Escherichia coli. Indian J. Med. Res., 62, 1974: 1195-1201.

BICHAT, M.: In STONE, K.: In: Disease of the joints and rheumatism. Heinemann, London, 1947.

BIRO, T. - FARKAS, T.: Crystal synovitis with generalized cartilage calcification. Magy. Traumatol. Orthop., 17, 1974:306-309.

BONDURANT, R. E. - HENRY, J. B.: Pathogenesis of ochronosis in experimental alkaptonuria of the white rat. Lab. Invest., 14, 1965: 62-64. 
BOZDĚCH, Z. - HORN, V.: Die funktionelle Regeneration nach Synovektomie im Experiment. Z. Ortop., 108, 1970: 98-104.

BOZDĚCH, Z. - HORN, V. - HORKÝ, D.: Synoviální blána a její regenerace. Cas. lék. čes., 112, 1973: 833-835.

BOZDĚCH, Z. - HORKÝ, D. - HORN, V.: Nové poznatky o ochronóze. Acta Chir. orthop. Traum. Cech., 42, 1975: 39-48.

BRODIE, B.: Cit. STONE, K. In: Disease of the joints and rheumatism. Heinemann, London, 1947.

CAMERON, H. U. - MACNAB, I.: Scanning electron microscopic studies of the hip joint capsule and synovial membrane. Can. J. Surg., 16, 1973: 388-392.

CASTOR, C. W.: The microscopic structure of normal human synovial tissue. Arthritis Rheum., 3, 1960: 140-151.

CCHIU, S. S.: Localization of intracellular gold - a study by light and electron microscopy. Ryumachi, 15, 1975: 54-73.

CHERNEY, D. D. - Di DIO, L. J. A. - RIBERIO, R. F. - CAMPOS, J. C. P. - COMPERE, E. L.: Subcellular structure of the synovial membrane in rabbits under experimental conditions. Path. Biol., 18, 1970: 601-611.

COCHRANE, W. - DAVIES, D. V. - PALFREY, A. J.: Absorptive functions of the synovial membrane. Ann. rheum. Dis., 24, 1965: 2-15.

COULTER, W. H.: The characteristic of human synovial membrane as seen with the electron microscope. Arthritis Rheum., 5, 1962: 70-80.

FUJITA, T. - INOUE, H. - KODAMA, T.: Scanning electron microscopy of the normal and rheumatoid synovial membranes. Arch. histot. jap., 29, 1968: 511-522.

GAUCHER, A. - FAURE, G. - NETTER, P.: Application of scanning electron microscopy in the evaluation of iron content of human synovial membrane. Sem. Hop. Paris, 52, 1976: $1543-1544$

GHADIALLY, F. N. - ROY, S.: Ultrastructure of rabbit synovial membrane. Ann. rheum. Dis., 25, 1966: 318-326.

GHADIALLY, F. N. - ROY, S.: Phagocytosis by synovial cells. Nature, 213, pp. 1041, 1967a.

GHADIALLY, F. N. - ROY, S.: Ultrastructure of synovial membrane in rheumatoid arthritis. Ann. rheum. Dis., 26, 1967b: 426-443.

GHADIALLY, F. N. - ROY, S.: Ultrastructure of synovial joints in health and disease. Butterworths, London, 1969.

GHADIALLY, F. N. - ORYSCHAK, A. F. - MITCHELL, D. M.: Nuclear fibrous lamina in pathological human synovial membrane. Virchows Arch. B., Zellpathol., 15, 1974b: 223-228.

GRYFE, A. - GARDNER, D. L. - WOODWARD, D. H.: Scanning electron microscopy of normal and inflamed synovial tissue of a rheumatoid patient. Lancet, $1969 \mathrm{I}$ : 156-157.

HAMERMAN, D. - STEPHENS, M. - BARLAND, P.: Comparative histology and metabolism of synovial tissue in normal and arthritic joints. In: Inflammation and disease of connective tissue. L. C. Mills and Moyer, J. H., eds. Philadelphia and London: Saunders 1961.

HOWLETT, C. R.: Pathology of coxofemoral arthropathy in young beef bulls: ultrastructure of synovium. Pathology, 6, 1974: 19-28.

HUNTER, W.: Cit. STONE, K. In: Disease of the joints and rheumatism. Heinemann, London, 1947.

HUTH, F. - SOREN, A. - ROSENBAUER, K. A.: Fine structural changes of the synovial membrane in arthrosis deformans. Virchows Arch., Path. Anat., 359, 1973: 201-211.

JAFFE, H. L.: Metabolic, degenerative and inflammatory diseases of bones and joints. München Berlin-Wien, Urban and Schwarzenberg, 1972.

JOHANSSON, H. E. - REJNÖ, S.: Light and electron microscopic investigation of equine synovial membrane. A comparison between healthy joints and joints with intraarticular fractures and osteochondrosis dissecans. Acta Vet., Scand., 17, 1976: 153-168.

KEY, J. A.: The reformation of synovial membrane in the knees of rabbits after synovectomy. J. Bone Jt Surg., 7, 1925: 793-815.

KLEIN, W.: The synovial membrane in chronic posttraumatic arthropathy. Z. Orthop., 112, 1974: $552-555$.

KREY, P. R. - COHEN, A. S.: Fine structural analysis of rabbit synovial cells. I. The normal synovium and changes in organ culture. Arthritis Rheum., 16, 1973: 324-340.

KREY, P. R. - SCHEINBERG, M. A. - COHEN, A. S.: Fine structural analysis of rabbit synovial cells. II. Fine structure and rosetteforming cells of explant and monolayer cultures. Arthritis Rheum., 19, 1976: 581-592.

LANGER, E. - HUTH, F.: Untersuchungen über den submikroskopischen Bau der Synovial Membrane. Z. Zellforsch., 51, 1960: 545-549. 
LEVER, J. D. - FORD, E. H. R.: Histological, histochemical and electron microscopic observation on synovial membrane. Anat. Rec., 132, 1958: 525-539.

LUCKENBILL, L. M. - COHEN, A. S.: Phagocytic function of the avian synovial membrane. Arthritis Rheum., 10, 1967: 517-537.

MAIBACH, E.: Histochemische Untersuchungen an die Synovial-membrane. Acta anat., Basel, 17, 1953: $175-200$.

MALDYK, E. - POLOWIEC, Z. - ABGAROWICZ, T.: Comparative histological examinations of normal synovial membranes of knee joints in young people and subjects over the age of 60. Reumatologia, 12, 1974: 313-320.

MITCHELL, N. - BLACKWELL, P.: The electron microscopy of regenerating synovium after subtotal synovectomy in rabbits. J. Bone Jt Surg., 50 A 1968: 675-686.

MUIRDEN, K. D. - SENATOR, G. B.: Iron in the synovial membrane in rheumatoid arthritis and other disease. Ann. rheum. Dis., 27, 1968: 38-48.

MUIRDEN, K. D. - PEACE, G.: Light and electron microscope studies in carragheenin, adjuvant and tuberculin induced arthritis. Ann. rheum. Dis., 28, 1969: 392-401.

ORYSCHAK, A. F. - GHADIALLY, F. N. - BHATNAGAR, R.: Nuclear fibrous lamina in the chondrocytes of articular cartilage. Amer. J. Anat., 118, 1974: 511-515.

ORYSCHAK, A. F. - GHADIALLY, F. N.: Evolution of aurosomes in rabbit synovial membrane. Virchows Archiv A, Zellpathol., 20, 1976a: 29-39.

POOLE, A. R. - HEMBRY. R. M. - DINGLE, J. T. - PINDER, I. - DING, E. F. COSH, J.: Secretion and localization of cathepsin D in synovial tissues removed from rheumatoid and traumatized joints. An immunohistochemical study. Arthritis Rheum., 19, 1976: $1295-1307$.

RAYNS, D. L. - HIGHTON, T. C.: Electron microscopy of synovial membrane. Ann. rheum. Dis., 25, 1966: 477.

REDLER, I. - ZIMNY, M. L.: Scanning electron microscopy of normal and abnormal articular cartilage and synovium. J. Bone Jt. Surg., 52 A, 1970: 1395-1404.

ROY, S.: Cell structure and function in synovial membrane. Ph. D. Thesis, University of Sheffield, 1966.

ROY, S. - GHADIALLY, F. N. - CRANE, W. A. J.: Synovial membrane in traumatic effusion. Ultrastructure and autoradiography with tritiated leucine. Ann. rheum. Dis., 25, 1966: 259-271.

ROY, S. - GHADIALLY, F. N.: Ultrastructure of normal rat synovial membrane. Ann. rheum. Dis., 26, 1967: 26-38.

STONE, K.: Diseases of the joints and rheumatism. Heinemann, London, 1947.

VAINIO, K.: A histochemical study on LAP activity in synovial membrane. Ann. rheum. Dis., 25, 1966: 253-258.

WALCOTT, W. E.: Regeneration of the synovial membrane following typical synovectomy. J. Bone Surg., 9, 1927: 67-78.

WASSILEV, W.: Electron microscopical studies on the development of synovial cells in the knee joint of the rat. Verh. Anat. Ges., 67, 1972: 387-392.

WASSILEV, W.: Ultrahistochemical localization of adenosine triphosphatase activity in the synovial membrane of rats. Histochemie, 37, 1973: 113-117.

WASSILEV, W.: Changes in the ultrastructure of the synovial membrane during growth and aging. Verh. Anat. Ges., 69, 1975: 527-431.

WATANABE, H. - SPYCHER, M. A. - RÜTTNER, J. R.: Ultrastructural study of the normal rabbit synovium. Pathol. Microbiol., 41, Basel, 1974: 283-292.

WATANABE, H. - SPYCHER, M. A. - RÜTTNER, J. R. - FEHR, K. - VELVART, M. - BÖNI, A.: Ultrastructural studies of rabbit synovitis induced by autologous IgG fragments. I. Proliferation of the living cells. Scand. J. Rheumatol. Suppl., 15, 1976a: 5-14.

WATANABE, H. - SPYCHER, M. A. - RÜTTNER, J. R. - FEHR, K. - VELVART, M. - BÖNI, A.: Ultrastructural studies of rabbit synovitis induced by autologous IgG fragments. II. Infiltrating cells in the sublining layer. Scand. J. Rheumatol. Suppl., 15, 1976b: $15-22$.

WEBB, F. W. - LOWE, J. - BLUESTONE, R.: Uptake of colloidal radioactive yttrium by synovial membrane. Ann. rheum. Dis., 28, 1969: 300-302.

WOLF, J.: Transition from synovial into chondral membrane. Folia morph., Praha, 22, 1974a: $151-160$.

WOLF, J.: Reinforcement of transitional zone between chondral and synovial membranes. Folia morph., Praha, 22, 1974b: 161-164.

WYLLIE, J. C. - MORE, R. H. - HAUST, M. D.: The fine structure of normal guinea - pig synovium. Lab. Invest., 13, 1964: 1254-1263.

WYSOCKI, P. - BRINKHOUS, K. M.: Scanning electron microscopy of synovial membranes. Arch. Path., 93, 1972: 172-177. 